\title{
MORTALITY OF YEARLING CHINOOK SALMON PRIOR TO \\ ARRIVAL AT LOWER GRANITE DAM, ON THE SNAKE RIVER
}

\author{
Progress Report \\ Prepared by \\ Albert Giorgi \\ Don Chapman Consultants

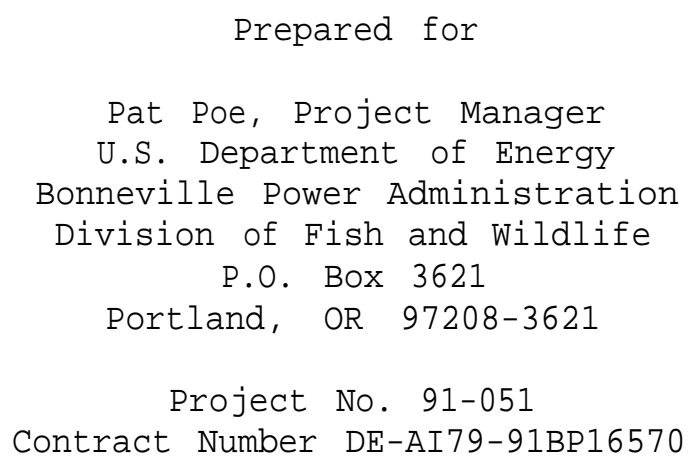




\section{Executive Summary}

Mark-recapture data at Lower Granite Dam indicate that few yearling chinook salmon (Oncorhvnchus tshawvtscha) smolts survive to that site after release from various hatcheries. Upriver stocks of yearling spring and summer chinook exhibit pronounced lossesen route to the dam. In 1989 and 1990, only about 8 to $18 \%$ of PIT-tagged representatives from McCall or Sawtooth hatchery were detected at the dam. General survival indices for these stocks'indicate that perhaps only 15 to $35 \%$ of the yearlings survived to that site. This suggests these stocks may sustain as much mortality traversing this unobstructed reach of river as the general population would passing through the entire hydroelectric complex.

As a basis of comparison, survival rates to the uppermost hydroelectric dam were estimated to be much higher, over two decades ago. During the years 1966 through 1968, Ice Harbor was the first dam encountered by downstream migrants on the Snake River. Raymond (1979) estimated survival of wild yearling chinook from trap sites on the Salmon River to Ice Harbor Dam during those years. Survival of wild yearling chinook salmon averaged $89 \%$ and ranged from 85 to $95 \%$ over those years. This is . approximately two to five times the survival I currently estimate for hatchery stocks in the drainage.

One possible explanation for the discrepancy between these estimates of smolt survival is the pedigree of the stocks. Estimates from the 1960s (Raymond 1979) were for wild stocks, while current estimates are derived from hatchery stocks. The poor survival of hatchery stocks could be attributable to inferior quality, or viability, of hatchery fish, e.g., as potentially associated with disease, smolt development or maladaptive behaviors.

Alternatively, it may be that the habitat in the migration corridor between the hatcheries and the dam cannot support the ever-increasing numbers of salmonids of all species currently being released from hatcheries. A part from acute mortality, investigators have found that starvation exerted a strong influence on energy reserves and survival in seawater challenge tests. 
Indications are that some of these stocks do not promptly initiate migration, because they are not adequately developed physiologically as smolts. This, in conjunction with water velocity related migratory dynamics, contributes to the protracted residence time in the migration corridor, particularly within Lower Granite Pool. Protracted riverine residence time increases the need for food. A number of investigations have documented that yearling chinook do feed as the migrate seaward. What is not apparent is whether suitabl'e prey items are available in adequate numbers, when fish are residing in a particular reach of river.

Perhaps of even greater concern is the potential for negative effects on wild stocks as they commingle with hatchery salmonids, in the migration corridor. Competition for food resources, as well as the potential for disease transmission, displacement of wild fish, and perhaps even predation from larger hatchery steelhead juveniles are mechanisms of mortality that could be of concern, but have received little attention.

General survival indices for PIT-tagged wild stocks in the Snake River Basin suggest that mortality from summer (when tagged as parr) to arrival the following spring at Lower Granite Dam appears quite high, near approximatey $90 \%$. It is possible that the magnitude of the loss is representative for the population. However, there are laboratory observations that suggest that an assortment of tags and marks may induce some effects that are manifested as increased predation on tagged/ marked individuals. Furthermore, the currently available survival estimation procedure is only a general measure, and of undefined precision.

Until we can confidently identify the magnitude, causes and location of smolt loss upstream from Lower Granite Dam, it is difficult to formulate effective management activities that target specific problems and result in improved smolt survival.

Efforts have been initiated to develop a research plan that will provide insight into causes of, and ultimately solutions to, the apparent excessive mortality of juvenile chinook upstream from Lower Granite Dam. In the context of the proposed salmon stock listings under the Endangered Species Act, issues that potentially affect wild 
stocks of spring chinook salmon probably warrant immediate consideration and resolution. The research plan should include investigations that:

1) Identify the agents causing smolt mortality, i.e., smolt condition, limited resources, or predation.

2) Confidently quantif) the magnitude of smolt mortality to arrival at Lower Granite Dam, particularly for wild stocks.

3) Assess the extent of negatibe interaction between hatchery and wild fish, including competition.

4) Determine if the survival of marked, particularly PIT-tagged, fish is representative of the general population, especially for wild stocks.

5) Determine how to correct or offset any identified mortality problems.

6) Assess annual variability in presmolt and smolt survival in relation to hydrographic conditions. 


\section{TABLE OF CONTENTS}

Background $\ldots \ldots \ldots \ldots \ldots \ldots \ldots \ldots \ldots \ldots \ldots \ldots \ldots$

Indices of Smolt Survival: Hatchery Stocks $\ldots \ldots \ldots \ldots \ldots \ldots \ldots$

Potential Mechanisms Affecting Smolt Mortality $\ldots \ldots \ldots \ldots \ldots \ldots \ldots$

Smolt Vitality: Hatchery vs. Wild Stocks $\ldots \ldots \ldots \ldots \ldots \ldots \ldots$

CanyingCapaciry $\ldots \ldots \ldots \ldots \ldots \ldots \ldots \ldots \ldots \ldots \ldots \ldots$

Species Interaction $\ldots \ldots \ldots \ldots \ldots \ldots \ldots \ldots \ldots \ldots \ldots \ldots \ldots$

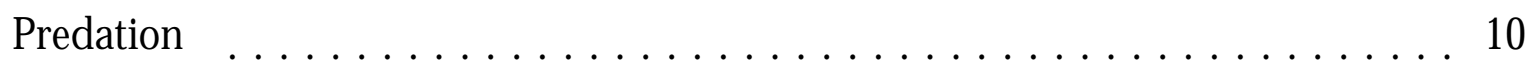

Factors Affecting Residence Time In Lower Granite Reservoir . . . . . . . . . 11

Wild Fish Mortality: Parr to Smolt $\ldots \ldots \ldots \ldots \ldots \ldots \ldots \ldots$

Tag Effects $\ldots \ldots \ldots \ldots \ldots \ldots \ldots \ldots \ldots \ldots \ldots \ldots \ldots \ldots \ldots \ldots$

Accuracy of Survival Estimates $\ldots \ldots \ldots \ldots \ldots \ldots \ldots \ldots \ldots$

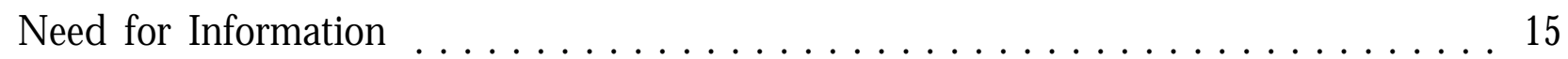

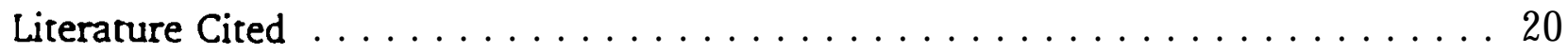




\section{List of Tables}

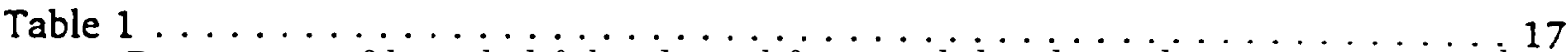

Percentage of branded fish released from each hatchery that were estimated as recovered at Lower Granite Dam. Percentages were calculated from release numbers and passage indices reported in the Fish Passage Managers reports for those years (FPC 1986 through 1991, McConnaha, et al. 1985).

Table 2

1989 PIT tag recoveries at Lower Granite Dam and estimated survival to that site, for wild/ natural chinook salmon. Parr were tagged in their natal streams the summer preceding the outmigration year, 1989. No spiil occurred at the recovery dam, and PIT tag recaptures were expanded by FGE $=0.53$ to estimate survival from tagging to recapture in the spring. Recovery data for 1989 were from Matthews et al. (1990).

Table 3 1990 PIT tag recoveries at Lower Granite Dam and estimated survival to that site, for wild/ natural chinook salmon. Parr were tagged in their natal streams the summer preceding the outmigration year, 1990. $\mathbf{~} \mathbf{b}$ spill occurred at the recovery dam, and PIT tag recaptures were expanded by FGE $=0 . S 3$ to estimate survival from tagging to recapture in the spring. Recovery data for 1990 are as of September 1991. 


\section{Background}

Lower Granite Dam is situated on the Snake River in Washington State, approximately 696 kilometers upstream from the mouth of the Columbia River. It is the first hydroelectric facility downstream that migrating salmonids encounter after they leave hatcheries, or volitionally emigrate from natural production and rearing areas in the Clearwater and Salmon River drainages.

Mark-recapture data at Low er Granite Dam indicate that few yearling chinook salmon (Oncorhvnchus tshawvtscha) smolts are recovered at rhat site after release from various hatcheries. From 1985-1990, the percentage of freeze-branded yearling chinook recovered from spring releases at Dworshak National Fish Hatchery has averaged $22.3 \%$ (Table 1). From 1984 through 1989, based on the passage index, the estimated recovery of chinook released from Rapid River, Sawtooth, and McCall hatcheries has averaged 16.8, 5.9, and 9.0\%, respectively (Table 1). The estimate for McCall Hatchery does not include 1988, when too few fish were captured to permit calculation of a passage index. It should be noted that the passage index adjusts for an unmeasured loss of marked fish through the spillway by assuming spillway passage is proportional to the percentage of the total flow that is spilled. When no spill occurs, the passage index equals the number of marked fish estimated as entrained in the juvenile salmonid collection system at the dam.

In most cases, the brand data probably underestimate the actual number of marked fish collected at that site. PIT-tagged fish from some of those same hatcheries have been recovered in appreciably higher proportions. For instance, in 1989, 10.5\% of the PIT-tagged chinook released from Sawtooth hatchery were recaptured at Lower Granite Dam (Matthews et al. 1990), whereas only 3.9\% of the branded fish were recorded as being collected at the dam. That same year $17.8 \%$ of the PIT-tagged fish released from McCall Hatchery were detected at the dam, yet only $6.0 \%$ of the brands were estimated as collected. However, the discrepancy in recovery proportions between mark types was not so apparent for fish released from Dworshak hatchery. In 1988 and 
1989, $23.5 \%$ and $28 \%$ of the PIT-tagged groups used as controls for a NMFS experiment, were detected at the dam (Giorgi et al. 1990 and 1991) This is similar to the recovery percentages observed for branded production fish (Table 1).

In studies conducted at McNary Dam, McCutcheon and Giorgi (1989 and 1990) observed lower recovery proportions of freeze-branded versus PIT-tagged smolts. They attributed much of the difference to inconsistent expression of the brands on the body of the fish, as well as human error associated with brand reading and recording. Since PIT tags have been shown to provide more accurate recovery data, I used the tag data to estimate a general index of smolt survival to Lower Granite Dam.

Indices of Smolt survival: Hatchery Stocks

Only fish entering the powerhouse intakes and guided into the bypass system are enumerated by electronic PIT tag detectors. Thus, recovery percentages documented in the collection system do not equate to survival, since some proportion of the tagged fish do not enter the collection system but pass through the turbines or pass through the spillway. PIT tag detection efficiency has typically exceeded $97 \%$ at Lower Granite since 1986 (Prentice, et al. 1988, and personal communication with E. Prentice), thus rag loss due to reduced reading efficiency is considered negligible in this assessment. Furthermore, loss of fish over the spillway is not an issue, since no spill occurred at Lower Granite Dam during the years used in this analysis. However, an estimate of the sampling efficiency of the collection system, in this case the proportion of fish guided from the turbine intake into the collection system, is necessary to estimate the total numbers of tagged fish arriving at the dam, and to calculate a survival estimate.

Swan et al. (1985, and 1986) estimated the proportion of yearling chinook guided from turbine intakes by submersible traveling screens (STS) at Lower Granite Dam. The average fish guidance efficiency (FGE) values for those years estimated over a variety of test conditions were: $50 \%(n=24)$ in 1984 , and $52 \%(n=14)$ in 1985 . In 1986 (Ledgerwood et al. 1987) and 1989 (Swan et al. 1990) the average FGE with 
standard ST'S and standard operating gate position was 53.4 and S7.3\%, respectively. The mean of the estimates is $53.2 \%$. If these estimates are generally representative of the overall FGE during the outmigration, then expanding the average PIT tag detection percentages by FGE $=0.53$, yields general estimates of survival from release to arrival at the dam as:

\begin{tabular}{|l|c|c|c|c|c|}
\hline & \multicolumn{2}{|c|}{ Dworshak } & \multicolumn{2}{c|}{ Sawtooth } & McCall \\
\hline & 1988 & 1989 & 1989 & 1990 & 1989 \\
\hline Recovery (\%) $=$ & 23.5 & 28.0 & 10.5 & 8.0 & 17.8 \\
\hline Survival to LGR (\%) $=$ & 44.3 & 52.8 & 19.8 & 15.1 & 33.6 \\
\hline \hline
\end{tabular}

These estimates suggest there are massive losses of yearling chinook en route to the first hydroelectric dam encountered by downstream migrants.

As a basis of comparison, survival rates to the uppermost hydroelectric dam were estimated to be much higher, over two decades ago. During the years 1966 through 1968, Ice Harbor was the first dam encountered by downstream migrants on the Snake River. Raymond (1979) estimated survival of wild yearling chinook from trap sites on the Salmon River to Ice Harbor Dam during those years. Survival of wild yearling chinook salmon averaged $89 \%$ and ranged from 85 to $95 \%$ over those years. This is approximately two to five times the survival I currently estimate for hatchery stocks in the drainage.

The current estimates of smolt mortality to Lower Granite Dam for hatchery stocks emanating several hundred kilometers upstream (Sawtooth and McCall hatcheries) are as great as the magnitude of smolt loss estimated to occur through the entire hydroelectric complex during the late 1970s and early 1980s. Sims and Ossiander (1981) and Sims et al. (1983) estimated about 80 to $85 \%$ survival for smolts per project, in moderate to high runoff volume years. This equates to approximately 17 to $27 \%$ sunrival past all eight hydroelectric dams. This is nearly equivalent to the 
survival realized by Sawtooth and McCall hatchery stocks en route to the first hydroelectric dam. My estimates suggest that some of these stocks sustain as much mortality traversing this unobstructed reach of river as the general population would in passing through the entire hydroelectric complex. Furthermore, if the high mortality upstream from the first project reflect generally poor performance or vitality, these stocks cannot be expected-to survive well during stressful passage through the hydroelectric complex.

Potential Mechanisms affecting Smolt Mortality

Smolt Vitalirv: Hatcherv vs. Wild Stocks

One possible explanation for the discrepancy between current and historical estimates of smolt survival is the pedigree of the stocks. Estimates from the 1960s (Raymond 1979) were for wild stocks, while current estimates are derived from hatchery stocks. The poor survival of hatchery stocks could be attributable to inferior quality, or viability, of hatchery fish. Both Raymond (1988) and Williams (1989) suggested that this may be a key factor responsible for the poor performance of Snake River stocks in general. In support of this contention there is considerable evidence that bacterial kidney disease (BKD) is pervasive in spring and summer chinook stocks inhabiting the Snake River drainage. Park et al. (1986) and Matthews et al. (1987) found a strong association between the incidence of BKD and mortality observed in migrants that were captured at Lower Granite Dam and held for extended periods in saltwater. They observed that 63 to $69 \%$ of the observed mortalities had BKD lesions. Infected fish may be debilitated in other respects as well, exacerbating effects associated with passage conditions.

Investigators at the U. S. Fish and Wildlife designed a more elaborate research program that focused on determming the extent and severity of the BKD problem in Snake River chinook populations. Results from that ongoing study have been alarming. In 1988, the prevalence of BKD observed in yearling chinook sampled at Lower Granite 
and Little Goose Dam was 86 and 92\%, respectively, as assayed with the enzymelinked immunosorbent assay (Pascho and Elliott 1989). Furthermore, all samples of three-fish tissue pools from wild/ natural populations were positive for BKD, but the infection levels were low. The authors caution that the presence of BKD-negative fish may have been masked by the inclusion at least one positive fish in a pooled sample. At Lower Granite Dam in 1989, indications were that the prevalence and infection levels at Lower Granite Dam (the only sampling site on-the Snake River that year) were higher than observed in 1988 (Elliott and Pascho 1991). Wild/natural populations showed patterns similar to 1988 . Beeman et al. (1990) report that in 1989 the incidence of BKD in fish sampled at the hatcheries ranged from 92 to $100 \%$, and 81 to $100 \%$ in samples of yearling chinook collected at hydroelectric dams.

There are indicators apart from the presence of disease agents that suggest the performance of certain hatchery stocks may be compromised. Beeman et al. (1990) monitored changes in plasma glucose, chloride and cortisol for assorted hatchery stocks of spring and summer chinook subjected to a handling stress challenge. This provided a measure of a given stock's physiological capability to respond to a stressful condition. They noted that some stocks exhibited responses they characterized as undesirable, including both the McCall stock of summer chinook and spring/ summer chinook from the Sawtooth hatchery. Those are the same stocks that had the poorest survival to Lower Granite Dam. Earlier studies conducted by the same group of investigators showed variable responses thar they attributed to unusual or differing test protocols (Rondorf et al. 1988 and 1989). It would appear that these types of assessments provide at least one means to quantify the vitality of chinook stocks in the Snake River Basin.

In a complementary investigation, physiologists are attempting to ascertain the importance of physiological condition of hatchery stocks, with respect to the extent of smolt development expressed in the hatchery, and survival to adulthood. Zaugg et al. (1991) found tha spring chinook at Dworshak NFH showed little or no development of smolt characteristics up to the time of release. There is evidence that the extent of 
smolt development can affect migratory and passage behavior, performance, and presumably survival of downstream migrants (Giorgi et al. 1990, Giorgi 1990, Giorgi et al. 1991, Muir et al. (in preparation]). However, those observations are based on hatchery stocks and information regarding the physiological and behavioral characteristics of wild stocks is not available.

\section{Carrying Capacity'}

Alternatively, it may be that the habitat upstream from Lower Granite Dam cannot support the unprecedented, massive numbers of salmonids, of all species, currently being released from hatcheries. In 1988 and 1989, approximately 28 and 23 million juvenile salmonids, respectively, were released into the Snake River or its tributaries (FPC 1990). Coupled with wild production, the total number of juvenile salmonids could have approached 25 to 30 million in those years. In contrast, the number of smolts estimated at Ice Harbor Dam in the 1960s was a fraction of that. (1967 and 1969) Raymond presented the following data:

\begin{tabular}{|c|c|c|c|}
\hline \multicolumn{5}{|c|}{ Estimated Number of Smolts at Ice Harbor (millions) } \\
\hline Year & Chinook & Steelhead & Total \\
\hline 1964 & 3.3 & 1.5 & 4.8 \\
\hline 1965 & 2.3 & 1.2 & 3.5 \\
\hline 1966 & 5.4 & 2.1 & 7.5 \\
\hline 1968 & 2.4 & 4.5 & 6.9 \\
\hline
\end{tabular}

These estimates include both wild and hatchery smolts. At some point the Carring capacity can no longer support the endlessly increasing number of pre-smolts and smolts. 'Carrying capacity' here refers not to summer rearing, but to the capacity of the migration corridor to support smolts and pre-smolts in the several weeks just before and during the migration co the sea. Some of the hatchery populations appear to reside 
in Lower Granite Pool for up to three weeks or more. For example, the FPC (1991) estimated that in 1990 the median travel time for spring chinook from Dworshak NFH to Lower Granite Dam ranged from 20 to 31 days. The vast majority of Dworshak yearling chinook arrive at the head of Granite Pool within 48-h after release. If the carrying capacity is being taxed, protracted pool residence times can only exacerbate the situation. Furthermore, if the infusion of vast numbers of hatchery fish has a having a pronounced impact on carrying capacity, we can only speculate as to the effects on wild/ natural stocks.

Similar issues were raised by Conner (1989), while studying fall chinook rearing requirements in the Clearwater River. He suggested that increasing numbers of hatchery pre-smolts and smolts released into the mainstream and its tributaries may be influencing upriver production by saturating rearing habitat. He concluded that research on this topic was warranted.

Information regarding food habits of migrating yearling chinook, as well as food availability, is very limited. Bennett and Shrier (1986) found that during the spring, juvenile chinook salmon residing nearshore in shallow-water areas of Lower Granite Reservoir consumed considerable amounts of larval or juvenile fish of other species. Fish flesh was the predominant material by weight in the stomach (SO\%), with dipterans comprising the second most abundant food item (31\%). Whereas, chinook collected offshore, in deeper waters, fed mostly on dipterans (78\%), and fish were not observed in the diet. It is well to note that this was not an intensive research effort to define food habits, but a small part of a broader program. Samples were limited in both quantity and frequency of sampling. Also, the size and age of chinook sampled was not reported, thus it was not possible to ascertain whether subyearlings or yearlings comprised the samples.

Preliminary data from the NMFS and USFWS indicate a contrasting picture of yearling chinook food habits as observed at Lower Granite Dam (Bill Muir, personal communication). Fish were collected at Lower Granite Dam serially throughout much 
of the outmigration, in at least two years, 1987 and 1989. One year, Coroohium SDD. was the predominant food item and the next year it was absent in the diet. Furthermore, guts were generally void of any food items the second year.

Coronhium is an benthic gammarid amphipod that periodically migrates vertically in the water column (Wilson 1983). Muir and Emmett (1988) suggest that this behavior makes them readily available to downstream migrant salmonids. They found that during the spring at Bonneville Dam, two Coroohium species w ere the dominant prey item, not only for yearling chinook, but all salmonid species examined.

Surprisingly, Bennett et al. (1991) did not report the presence of this amphipod genus in the benthic samples they collected in Lower Granite Pool. Perhaps the amphipod population is geographically restricted or highly variable in productivity, as Mr. Muir's preliminary data from Lower Granite Dam would suggest.

Rondorf et al. (1985) measured the daily ration and food consumption of chinook salmon in the Columbia River in 1982 and 1983. They found that fish captured near Crescent Bar consumed less food than those sampled at sites downstream near Arlington. They suggested the upstream fish may have been recently-released hatchery fish not yet adapted to efficiently feed on natural prey items.

Information available at this time clearly indicates that yearling chinook do feed as they migrate. What is not clear is whether suitable prey items are available in adequate numbers, when fish are residing in a particular reach of river.

If food is limiting upstream from Lower Granite Dam, the duration of yearling chinook residence time in waters upstream from the dam is an important parameter influencing the bioenergetic profile of these animals. Rondorf et al. (1985), using hatchery-reared spring chinook salmon, found that starvation exerted a strong influence on energy reserves and survival in seawater challenge rests. To date, similar studies have not been conducted on active migrants. But, if the responses are similar, protracted residence time in unproductive waters could place downstream migrants at a 
disadvantage. This would make wild fish survival a function of hatchery fish abundance and duration of migration.

\section{Species Interaction}

A part from direct competition for resources, inter- and intraspecific interaction of wild and hatchery salmonids can rake other forms. Transmission of disease, displacement of wild fish, and predation of hatchery on wild fish are potential negative interactions (Marnell 1986). For instance, Hillman and Mullan (Hillman and Mullan 1989) observed that thinning releases of hatchery-reared age 0 chinook "pulled" wild chinook and steelhead from stream margins and moved together downstream. Predatory trout preferentially selected the smaller wild fish from the mixed population that was moving downstream. The authors noted that the hatchery fish were nearly twice the length of the wild chinook.

These issues are critical. We must determine the ecological needs of these fish and the limits of this ecosystem, as well as the condition and viability of the fish released from hatcheries. At this time, the evidence indicates that vast numbers of salmon released from hatcheries die before they encounter the first hydroelectric dam, while the potential for competition with natural/ wild fish goes unassessed.

\section{Predation}

The length of time juvenile chinook spend in environs upstream from the dam also affects the amount of predation mortality incurred. Predaceous piscivores, especially northern squawfish, $\underline{P t v c h o c h e i l u s ~ o r e g o n e n s i s, ~ c o n s u m e ~ c o n s i d e r a b l e ~}$ numbers of salmonid smolts as they migrate seaward. Poe and Rieman (1988) found that squawfiih were the dominant predator of salmonid smolts, accounting for $78 \%$ of the total loss in John Day Reservoir. Furthermore, they documented that the highest losses per unit area occurred near rhe tailrace of McN ary Dam and the forebay of John Day Dam. Peterson et al. ( 1991) observed that predatory fish also congregate in the 
forebays elsewhere. If smolts also congregate in forebays and remain there for protracted periods, increased mortality associated with predation would be expected.

Currently, there is no direct evidence indicating where, or for how long, yearling chinook salmon stage, or congregate, within Lower Granite Reservoir. Chapman et al. (1991) postulated that the-short response time between fluctuations in flow and corresponding changes in passage indices, less than $24 \mathrm{~h}$ in many cases, suggests that fish are being drawn into the powerhouse from a location in the forebay relatively close to the dam. Thus, the potential exists for predation in that area to be an important mechanism of smolt loss within the reservoir.

\section{Factors Affecting Residence Time In Lower Granite Reservoir}

Mechanisms potentially affecting smolt mortality can be split into two general categories; 1) those that are associated with smolt vitality, condition, or physical performance and that are independent of migration speed, and 2) mechanisms that can be influenced by smolt migration speed, such as the amount of time smolts are exposed to either predators or habitat of limited carrying capacity. The extent to which smolt residence time in Lower Granite Reservoir can be influenced by fish passage management activities is important with regard to possibly offsetting the second category of mechanisms of mortality.

There is evidence to indicate that yearling chinook salmon in Lower Granite Reservoir respond to prevailing flow volumes, or to water velocity (Buettner and Nelson 1989, 1990a and 1990b). Those investigators demonstrated a significant inverse relationship between flow and median smolt travel time from rrap sites at the head of the reservoir to Lower Granite Dam. Chapman et al. (1991) suggested that the observed response may be only in part due to water velocity, and that the process of smolt development over the course of the outmigration may also be influential. In support Beeman et al. (1990) found that gill ATPase, an indicator of smolt development, increased over the course of the spring outmigration at the Snake River 
trapsite, concomitant with increases in flow. Beeman et al. (1990) appropriately noted that these two independent variables were intercorrelated, a condition that can confound the interpretation of any relationship associated with smolt travel time.

Furthermore, there is direct experimental evidence that indicates developmentally advanced (more-smolted) yearling chinook salmon migrate significantly faster than lesssmolted counterparts. In the spring of 1989 and 1990, physiologically advanced yearling chinook (those that displayed elevated gill ATPase) were released from Dworshak National Fish Hatchery and passed Lower Granite Dam a week sooner than corresponding control groups (Giorgi 1990, Giorgi et al. 1991, Muir et al. in prep.).

Collectively, these investigations indicate that both the extent of smolt development, as well as water velocity affect smolt travel time. However, correlations with either single independent variable can be misleading, since results can be confounded when correlations among the independent variables are pronounced. It can then be difficult to accurately quantify the proportion of the observed response that flow augmentation causes.

It may be possible to resolve these confounding effects with experiments designed to isolate the effects of a particular variable, perhaps similar to those conducted by the NMFS (Giorgi 1990, Muir et al. in prep.). Alternatively, systematic serial releases of marked smolts at strategic sites, which are assayed for smolt development, coupled with perturbations in the hydrograph (naturally occurring or intentionally imposed) are necessary. This approach will potentially reveal effecrs that are now masked by the intercorrelation of the two important independenr variables.

Wild Fish Mortality: Parr to Smolt

During the summers since 1988, NMFS and the Idaho Department of Fish and Game have PIT-tagged wild/ natural chinook parr in various srreams throughout Idaho and Oregon. During rhe subsequent spring and summer months, these fish are detected 
as they pass Lower Granite Dam, as well as other dams equipped with detectors. These fish provide an opportunity to estimate survival from the time of marking until passage at Lower Granite Dam. Assuming the same conditions and applying the same average FGE values as in the preceding analysis for hatchery fish, I estimated survival for specific stream-populations of chinook salmon for the 1989 and 1990 out-migration years (Table 2). In 1989, survival indices for fish from all streams ranged from 1.5 to $16.6 \%$, with a mean of $9.5 \%$. In 1990 , the sunrival indices for all stocks were similar and ranged from 0.8 to $18.5 \%$, with a mean of $11.2 \%$. These values are several times lower than anticipated by Matthews et al. (1990). These survival indices cannot be compared directly to survival of hatchery fish as calculated previously, because the wild fish were tagged the preceding summer and incurred over-winter mortality.

These levels of survival may appear unreasonably low. However, Seelbach (1987), studied steelhead in a tributary of Lake Michigan and estimated overwinter survival to be as low as 13\%. But, he also observed a high of $90 \%$ over three years of study. Perhaps more importantly, he observed a strong positive relationship between the estimated overwinter mortality and the severity of the winter as indexed by climatological factors including air temperature and precipitation. Furthermore, due to the pronounced environmental effects, he found no correlation between smolt production and the number of spawners entering that river. Winters at the higher elevations in the Snake River Basin can be severe. The 1988-89 and 1989-90 winters were harsh, characterized by low precipitation, streamflow and temperatures. The survival estimates from summer-parr to smolt were low and averaging 9.5\% and $11.2 \%$. It is plausible that these severe winter conditions are in part a cause of the low estimated survival.

Conversely, as suggested previously, the carrying capacity of the system in spring may nor support the vast numbers of fish (primarily of hatchery origin) utilizing it. Reasonably, we would expect that such an effect would be most pronounced in Lower Granite Pool, where all the populations mass and the habitat is geographically restricted. It is also plausible that such conditions could promote disease transmission 
and other interactions detrimental to wild fish. Under this scenario the wild fish may be the unfortunate victims of overzealous hatchery outplant programs. Research regarding this fundamental ecological issue is sorely needed.

These parr to smolt survival estimates, which were calculated for brood years when adult returns and associated seeding were low, are inconsistent with estimates of egg to smolt survial presented in the Integrated System Plan (CEWWA 1990). Egg to smolt survival estimates calculated in that document ranged from 22 to $26 \%$ at low seeding levels. My survival estimates for parr to smolt were less than half those estimates.

\section{$\underline{\text { Tag Effects }}$}

Some of the mortality may be due to tag effects. However, Prentice et al. (1988), in controlled laboratory experiments found the tag to be benign, and that it did not impair performance. The only observed effect was that the tagging process retarded growth very slightly in some experimental groups. In contrast, current investigations by the same group of researchers indicate that any mark or tag may negatively affect juvenile survival. Preliminary findings by Maynard et al. (1990) indicated that steelhead parr that were either tagged or branded were preyed-on significantly more than corresponding controls. [t is reasonable to expect that in the wild this could put tagged fish at a disadvantage. The potential for expression of tag effects in the natural environment is a topic that deserves investigation.

Accuracy of Survival Estimates

Surviva estimates calculated in this analysis are derived using FGE estimates that were based on fykenet and gatewell sampling protocols conducted under standardized operating conditions. This is the measure of collection, or sampling, efficiency that I applied to mark recovery data to estimate survival in years when no spill occurred. It is possible, perhaps likely, that such estimates do not accurately reflect the functional 
FGE during the passage of a particular marked group of fish. At least one investigation suggested that collection efficiency at Lower Granite Dam could be considerably lower than the prevailing FGE estimates. Sims et al. (1983) released freeze-branded yearling chinook several kilometers upstream from Lower Granite Darn and subsequently sampled the fish as they passed the dam. Based on recovery proportions of marked fish, they indirectly estimated that only $\mathbf{2 4} \%$ of the yearling chinook entering the turbine intakes entered the collection system However, there were certain caveats associated with that analysis: estimates were based on recaptures from only four marked groups, and no observations were actually made when spill was not occurring, i.e., they were extrapolated estimates. Furthermore, McCutcheon and Giorgi (1989 and 1990) demonstrated that brand recovery data often underestimate the true number of marked individuals in the collected population.

If future investigations are to rely on collection or sampling efficiency estimate to calculate survival, considerable effort will need to be directed at properly defining those efficiencies. Steuhrenberg and Johnson (1990) have conducted such investigations at McNary Dam and are still continuing the evaluation. Their study could serve as a guide for any future investigations.

Concomitantly, or alternatively, other methods for estimating survival should be considered. Some protocols are now being formulated within the BPA-sponsored effort to design protocols for estimating smolt survival, which is being coordinated by Dr. Dennis Dauble of Battelle Northwest Laboratory. If appropriate, those methods could be used to estimate smolt loss upstream from Lower Granite Dam.

\section{Need for Information}

Until we can confidently identify the magnitude, causes and location of smolt loss upstream from Lower Granite Dam, it is difficult to formulate effective management activities that target specific problems and result in improved smolt survival. Solutions to problems associated with either predation, carrying capacity, or hatchery smolt 
vitality may be fundamentally different. Furthermore, a clearer understanding of smolt requirements, condition and migratory dynamics can provide insight relative to improving survival as smolts migrate through the hydroelectric complex downstream from Lower Granite Dam. For instance, if smolt condition were found to be so poor that their performance was unduly compromised, smolts may expire at unexpectedly high rates as they traverse the hydroelectric complex, even under relatively good passage conditions.

The task currently is to develop a research plan that will provide insight into causes of, and ultimately solutions to, the apparent excessive mortality of juvenile chinook upstream from Lower Granite Dam. [n the context of the proposed salmon stock listings under the Endangered Species Act, issues that potentially affect wild stocks of spring chinook salmon probably warrant immediate consideration and resolution. The research plan should include investigations thar:

1) Identify the agents causing smolt mortality, i.e., smolt condition, limited resources, or predation.

2) Confidently quantify the magnitude of smolt mortality to arrival at Lower Granite Dam, particularly for wild stocks.

3) Assess the extent of negative interaction between hatchery and wild fish, including competition.

41 Determine if the survival of marked, particularly PIT-tagged; fish is representative of the general population, especially for wild stocks.

5) Determine how to correct or offset any identified mortality problems.

6) Assess annual variability in presmolt and smolt survival in relation to hydrographic conditions. 
Table 1. Percentage of branded fish released from each hatchery that were estimated as recovered at Lower Granite Dam. Percentages were calculated from release numbers and passage indices reported in the Fish Passage Managers reports for those years (FPC 1986 through 1991, McConnaha, et al. 1985).

\begin{tabular}{||c|c|c|c|c||}
\hline \hline \multicolumn{5}{|c||}{ \% Recovered at LGR } \\
\hline Year & Dworshak & Rapid R & Sawtooth & McCall \\
\hline 1984 & -- & 10.7 & 8.8 & 11.9 \\
\hline 1985 & 27.7 & 27.6 & 10.8 & 16.4 \\
\hline 1986 & 11.6 & 23.7 & 6.3 & 14.1 \\
\hline 1987 & 18.0 & 7.2 & 1.9 & 3.5 \\
\hline 1988 & 28.9 & 9.9 & 3.7 &. \\
\hline 1989 & 22.7 & 17.4 & 3.9 & 6.0 \\
\hline 1990 & 25.0 & 21.2 & 6.2 & 1.9 \\
\hline Mean & 22.3 & 16.8 & 5.9 & 9.0 \\
\hline \hline
\end{tabular}


Table 2. 1989 PIT tag recoveries at Lower Granite Dam and estimated survival to that site, for wild/ natural chinook salmon. Parr were tagged in their natal streams the summer preceding the outmigration year, 1989. No spill occurred at the recovery dam, and PIT tag recaptures were expanded by $\mathrm{FGE}=0 . \mathrm{S3}$ to estimate survival from tagging to recapture in the spring. Recovery data for 1989 were from Matthews et al. (1990).

\begin{tabular}{|l|c|c|c|c||}
\hline \multicolumn{1}{|c|}{ Tag Site } & \# Released & $\begin{array}{c}\# \\
\text { Recapture }\end{array}$ & $\begin{array}{c}\text { \% } \\
\text { Recapture }\end{array}$ & $\begin{array}{c}\text { Estimated } \\
\text { Survival }\end{array}$ \\
\hline Crooked R. & 2464 & 44 & 1.8 & 3.4 \\
\hline Red R. & 2532 & 21 & 0.8 & 1.5 \\
\hline E.F.Salmon R. & 742 & 57 & 7.7 & 14.5 \\
\hline Upper Sal. R. & 2720 & 69 & 2.5 & 4.7 \\
\hline Alturus Lk. Cr. & 415 & 20 & 4.8 & 9.1 \\
\hline Valley Cr. & 2251 & 65 & 2.9 & 5.5 \\
\hline Secesh R & 2178 & 19 & 8.8 & 16.6 \\
\hline Lake Cr. & 664 & 51 & 7.7 & 14.5 \\
\hline S.F. Salmon R & 2184 & 85 & 3.9 & 7.4 \\
\hline Grande Ronde R & 2984 & 242 & 8.1 & -15.3 \\
\hline Imnaha R & 1207 & 73 & 6.1 & 11.5 \\
\hline \hline
\end{tabular}


Table 3. 1990 PIT tag recoveries at Lower Granite Dam and estimated survival to that site, for wild/ natural chinook salmon. Parr were tagged in their natal streams the summer preceding the outmigration year, 1990. No spill occurred at the recovery dam, and PIT tag recaptures were expanded by $\mathrm{FGE}=0 . \mathrm{S3}$ to estimate survival from tagging to recapture in the spring. Recovery data for 1990 are as of September 1991.

\begin{tabular}{|l|c|c|c|c|}
\hline \multicolumn{1}{|c|}{ Tag Site } & $\begin{array}{c}\# \\
\text { Released }\end{array}$ & $\begin{array}{c}\# \\
\text { Recaptured }\end{array}$ & $\begin{array}{c}\text { \% } \\
\text { Recaptured }\end{array}$ & $\begin{array}{c}\text { Estimated } \\
\text { Survival }\end{array}$ \\
\hline Alturus Lk. Cr. & 1036 & 4 & 0.4 & 0.8 \\
\hline Valley Cr. & 2498 & 76 & 3.0 & 5.7 \\
\hline Secesh R. & 2359 & 155 & 6.6 & 12.5 \\
\hline Imnaha R. & 1986 & 160 & 8.1 & 15.3 \\
\hline Sulphur Cr. & 2509 & 166 & 6.6 & 12.5 \\
\hline Elk Cr. & 16 & 1 & 6.3 & 11.9 \\
\hline Marsh Cr. & 2496 & 178 & 7.1 & 13.4 \\
\hline Bear Val. Cr. & 1557 & 91 & 5.8 & 10.9 \\
\hline Big Cr. & 2026 & 145 & 7.2 & 13.6 \\
\hline Lostine R. & 84 & 8 & 9.5 & 15.3 \\
\hline
\end{tabular}




\section{Literature Cited}

Beeman, J., D. Rondorf, J. Faler, M. Free, and P. Haner. 1990. Assessment of smolt condition for travel time analysis. Annual Report 1989, to BPA, Contract DE-A17987BP3524S. $103 \mathrm{p}$.

Bennett, D., and F. Shrier. 1986. Effects-of sediment dredging and in-water disposal on fishes in Lower Granite Reservoir, Idaho-Washington. Completion Report to USACE, DACW68-85-C-0044. 143 p.

Bennett, D., J. Chandler, and G. Chandler. 1991 (preliminary draft). Lower Granite Reservoir in-water disposal test: monitoring fish and benthic community activity at disposal and reference sites in Lower Granite Reservoir, Washington, year two (1989). Completion Report to USACE, Walla Walla, WA. $168 p$.

Buetmer, E., and V. Nelson. 1989. Smolt condition and timing of arrival at Lower Granite Reservoir. Annual Report for 1988, to BPA, Portland, OR, Contract DOE/ BP11631-3. SO p.

Buettner, E., and V. Nelson. 1990a. Smolt condition and timing of arrival at Lower Granite Reservoir. Annual Report for 1987, to BPA, Portland, OR, Contract DOE/ BP11631-3. $71 \mathrm{p}$.

Buettner, E., and V. Nelson. 1990b. Smolt monitoring at the head of Lower Granite Reservoir. 1989 Annual Report to BPA, Portland, OR, Contract DOE/ BP-I 1631-3. 59p.

Chapman, D., and ten other authors. 1991. Status of Snake River chinook salmon. Technical Report submitted to the Pacific Northwest Utilities Conference Committee. 
Columbia Basin Fish and Wildlife Authority (CBFWA). 1990. Integrated system plan for salmon and steelhead production in the Columbia River Basin. CBFWA, Portland, OR. $449 \mathrm{p}$.

Conner, W. P. 1989. Mainstem Clearwater River study: assessment for salmonid spawning, incubation, and rearing. Nez Perce Tribe Research Report to BPA, Contract \# DE-AI79-87-BP37474. $130 \mathrm{p}$.

Elliott, D. G., and R J. Pascho. 1991. Juvenile fish transportation: Impact of bacterial kidney disease on survival of spring/ summer chinook salmon stocks. Annual Report of research to U. S. A rmy Corps of Engineers, Walla, WA, Contract E86880047. 107 p., plus appendices.

Fish Passage Center (FPC). 1986. Smolt monitoring program 1985 annual report, Volume 1. Annual report to BPA, Portland, OR. 71 p., plus appendices.

Fish Passage Center (FPC). 1987. Smolt monitoring program 1986 annual report, Volume I. Annual report to BPA, Portland, OR 133 p., plus appendices.

Fish Passage Center (FPC). 1988. Smolt monitoring program 1987 annual report. Annual report to BPA, Portland, OR $112 \mathrm{p}$.

Fish Passage Center (FPC). 1989. Fish passage managers 1988 annual report. Annual report to BPA, Portland, OR 84 p., plus appendices.

Fish Passage Center (FPC). 1990. Fish Passage Managers 1989 annual report. Annual Report to BPA, Portland, OR, Project No. 87-127. 80 p., plus appendices.

Fish Passage Center (FPC). 1991. Fish Passage Managers 1989 annual report. Annual Report to BPA, Portland, OR, Project No. 87-127. 77 p., plus appendices. 
Giorgi, A. E. 1990. Biological manipulation of migratory behavior: the use of advanced photoperiod to accelerate smoltification in yearling chinook salmon. Pages 108-114, 프 D. L. Park, Editor, Status and future of spring chinook salmon in the Columbia River Basin -- conservation and enhancement. NOAA Tech. Memo., NMFS F/ NWC-187.

Giorgi, A, W. Muir, W. Zaugg, and S. McCutcheon. 1990. Biological manipulation of migration rate: the use of advanced photoperiod to accelerate smoltification in yearling chinook salmon. Annual Report for 1988, to BPA, Portland, OR, Contract DE-AI7988BPSO301. $33 \mathrm{p}$.

Giorgi, A., W. Muir, W. Zaugg, and S. McCutcheon. 1991. Biological manipulation of migration rate: the use of advanced photoperiod to accelerate smoltification in yearling chinook salmon, 1989. Annual Report to BP\& Portland, OR, Contract DE-AI7988BPS0301. $38 \mathrm{p}$.

Hillman, T. W. and J. W. Mullan. 1989. Effects of hatchery releases on the abundance and behavior of wild juvenile salmonids. Pages 266-285 in Final Report submitted to Chelan County PUD.

Ledgerwood, R, G. Swan, and R Krcrna. 1987. Fish guiding efficiency of submersible traveling screens at Lower Granite Dam-1986. Ann. Report to USACE, Portland, OR. 19 p., plus appendices.

Mamell, L F. 1986. Impacts of hatchery stocks on wild fish populations. Pages 339-347 h R H. Stroud, editor, Fish Culture in Fisheries Management. American Fisheries Society, Bethesda, MD.

Matthews, G., D. L. Park, J. Harmon, C. McCutcheon, and A. Novotny. 1987. Evaluation of transportation of juvenile salmonids and related research on the Columbia and Snake Rivers-1986. NMFS Annual Report of Research to the USACE, Contract DACW68-84-H-0034. 34 p. plus appendices. 
Matthews, G., J. Harmon, S. Achord, 0. Johnson, and L. Kubin. 1990. Evaluation of transportation of juvenile salmonids and related research on the Columbia and Snake Rivers, 1989. NMFS Research Report to USACE, Contract DAW68-84-H-0034. 59 p., plus appendices.

Maynard, D., E. Prentice, D. Frost, and W. Waknitz. 1990 . The vulnerability to predation of tagged and marked steelhead par-r compared to untagged cohorts. Preliminary findings presented in NWAFC Quarterly Report, October - December 1990.

McConnaha, W., L. Bachau, and J. Jordan. 1985. Migrational characteristics of Columbia Basin salmon and steelhead, 1984. Water Budget Center annual report to BPA, Portland, OR 51 p., plus appendices.

McCutcheon, C. S., and A. E. Giorgi. 1989. An assessment of freeze brand and PIT tag recovery data at McNary Dam, 1987. NMFS Annual Report of Research to BPA, Contract \#DE-AI79-87BP34269.60 p.

McCutcheon, C. S., and A. E. Giorgi. 1990. An assessment of freeze brand and PIT tag recovery data for juvenile salmonids at McNary Dam. NMFS Annual Report of Research, 1988 to BPA, Contract \# DE-AI79-87BP34269. 28 p.

Muir, W. D., and R L. Emmett. 1988. Food habits of migrating salmonid smolts passing Bonneville Dam in the Columbia River, 1984. Regulated Rivers 2: I-10.

Muir et al. in preparation. Biological manipulation of migration rate: the use of advanced photoperiod to accelerate smoltification in yearling chinook salmon, 1990. Annual Report to BPA, Portland, OR

Park, D. C., G. M. Matthews, and T. E. Ruehle. 1986. Evaluation of transportation of juvenile salmonids and related research on the Columbia and Snake Rivers, 1985.

Report to USACE, Contract DACW68-84-H-0034. 
Pascho, R J., and D.G. Elliott. 1989. Juvenile fish transportation: Impact of bacterial kidney disease on survival of spring/ summer chinook salmon stocks. Annual report of research to U. S. Army Corps of Engineers, Walla Walla, WA, Contract E86880047. 88 p., plus appendices.

Peterson, C. D. Jepsen, R Nelle, R Shively, R Tabor, and T. Poe. 1991. System-wide significance of predation on juvenile salmonids in Columbia and Snake River reservoirs. Annual Report of Research 1990, to BPA, Portland, OR, Contract DE-A I79-90BP07096. $53 \mathrm{p}$.

Poe, T.P., and B. E. Rieman. 1988. Predation by resident fish on juvenile salmonids in John Day Reservoir, 1983-1986. Volume - Final Report of Research to BPA, Portland, OR, Contracts DE- AI79-82BP34796 and DE-AI79-82BP35097. 377 p.

Prentice, E., T. Flagg, and Scott McCutcheon. 1988. A study to determine the biological feasibility of a new fish tagging system, 1986-1987. NMFS Ann. Rep. of Res. to BPA. DOE BP-11982-3. 113 p.

Raymond, H. L. 1967. A summary of the 1966 outmigration of juvenile salmonids in the Columbia Basin. Research report, U. S. Bureau of Commercial Fisheries. 19 p.

Raymond, H. L. 1969. A summary of the 1968 outmigration of juvenile salmon and steelhead trout from the Snake River. Research report, U. S. Bureau of Commercial Fisheries. $12 \mathrm{p}$.

Raymond, H. 1979. Effects of dams and impoundments on migrations of juvenile chinook salmon and steelhead from the Snake River, 1966 to 1975. Transactions of the American Fisheries Society, $108(6)$ : 505-529. 
Raymond, H. 1988. Effects of hydroelectric development and fisheries enhancement on spring and summer chinook salmon and steelhead in the Columbia River Basin. North Amer. Jour. of Fish. Manag. 8(1):1-24.

Rondorf, D., M. Dutchk, A. Kolok, and M. Gross. 1985. Bioenergetics of juvenile salmon during the spring outmigration. Annual Report to BPA, Portland, OR, Contract DE-AI79- 82 BP35346, $78 p$.

Rondorf, D., J. Beeman, M. Free, and D. Liljegren. 1988. Correlation of biological characteristics of smolts with survival and travel time. A nnual Report for 1987, to BPA, Contract DE-AI79-87BP3524S. $96 \mathrm{p}$.

Rondorf, D., J. Beeman, J. Faler, M. Free, and E. Wagner. 1989. Assessment of smolt condition for travel time analysis. Annual Report for 1988, to BPA, Portland, OR, Contract DE-AI79-87 BP35245,98 p.

Seelbach, P. W. 1987. Effect of winter severity on steelhead smolt yield in Michigan: an example of the importance of environmental factors in determining smolt yield. American Fisheries Society Symposium 1: 441450.

Sims, C., A. Giorgi, R. Johnsen, and D. Brege. 1983. Migrational characteristics of juvenile salmon and steel head in the Columbia River Basin - 1982. Final Report to USACE, Portland, OR. 35 p., plus appendices.

Sims, C., and F. Ossiander. 1981. Migrations of juvenile chinook salmon and steelhead trout in the Snake River from 1973 to 1979. N MFS Report to U.S. Army Corps of Engineers. $31 \mathrm{p}$.

Steuhrenberg, L., and 0. Johnson. 1990. Evaluation of factors affecting collection efficiency estimates of chinook salmon and steelhead smolts at McNary Dam. 1988 Annual Report to BPA, Portland, OR. $30 \mathrm{p}$. 
Swan, G., R Krcma, and F. Ossiander. 1985. Development of an improved fingerling protection system at Lower Granite Dam. NMFS AM. Res. Report to USACE. 23 p., plus appendices.

Swan, G., R Krcma, and F.-Ossiander. 1986.. Continuing studies to improve and evaluate juvenile salmonid collection at Lower Granite Dam. NMFS Ann. Res. Report to USACE. 31 p., plus appendices.

Swan, G., B. Monk, J. Williams, and B. Sandford. 1990. Fish guidance efficiency of submersible traveling screens at Lower Granite Dam - 1989. Annual Report to USACE, WallaWalla, WA, ContractDACW68-84-H-0034.

Williams, G. 1989. Snake River spring and summer chinook salmon: can they be saved? Regulated Rivers 4: 17-26.

Wilson, S. L. 1983. The life history of Coronhium Salmonis in the Columbia River estuary. Master's thesis, Oregon State University, Corvallis, OR

Zaugg, W. S., and nine other authors. 1991. Smolt quality assessment of spring chinook salmon. Annual report to BPA, Portland, OR. Contract DE-A 179-89BP97300. $109 \mathrm{p}$. 